\title{
Phytopigments as biomarkers of selectivity in abyssal holothurians; interspecific differences in response to a changing food supply.
}

Tania Smith $^{\mathrm{a}, *}$, David S.M. Billett ${ }^{\mathrm{a}}$, George A. Wolff ${ }^{\mathrm{b}}$, Anu Thompson ${ }^{\mathrm{b}}$ and Paul A.

$$
\text { Tyler }^{\text {a }}
$$

${ }^{a}$ National Oceanography Centre, Southampton, European Way, Southampton, SO15 3ZX, UK

${ }^{\mathrm{b}}$ Department of Earth and Ocean Sciences, University of Liverpool, 4, Brownlow Street, Liverpool, L69 3GP, UK

*Corresponding author. Tel :+ 44 (0)2380 596 358; fax: + 44 (0)2380 596247

\begin{abstract}
Holothurians dominate the abyssal megabenthos. They are key consumers and bioturbators of surficial sediment. Compounds essential for holothurian reproduction, such as carotenoids, are in short supply in the deep ocean. Holothurians cannot synthesise carotenoids de novo; the compounds are supplied with the flux of phytodetritus. Therefore, the supply of these compounds may play an important role in regulating processes on the seafloor. This study examines the link between the diet of abyssal holothurians and their ovarian carotenoid biochemistry. Phytodetritus, surficial sediment, holothurian gut content and ovaries were sampled in June 2004 and in July 2005 at the Porcupine Abyssal Plain (PAP), NE Atlantic. Gut content chlorophyll a concentration showed that Amperima rosea, Peniagone diaphana and Oneirophanta mutabilis fed selectively on fresh organic matter, although when this is scarce, O. mutabilis was outcompeted and fed on more refractory material. All three
\end{abstract}


species display consistent ovarian carotenoid profiles and have relatively high carotenoid concentrations in their ovaries. Psychropotes longicauda, Paroriza prouhoi, Pseudostichopus aemulatus, P. villosus and Molpadia blakei fed less selectively and exhibited low ovarian carotenoid concentrations with inconsistent profiles. The results suggest that abyssal holothurian ovarian biochemistry is a complex function of OM supply, holothurian feeding guild and reproductive adaptation. Changes in upper ocean biogeochemistry, altering the composition of organic matter reaching the deep-sea floor, may favour certain holothurian species, as suggested by the interspecific differences in holothurian ovarian biochemistry. This may lead to large community changes as seen at the PAP, which can alter the reworking rates of sediment, probably affecting carbon burial. The study also demonstrated that using the presence of biomarkers in gut contents to infer feeding selectivity should be used with caution. Only biomarkers in gut contents that are not present in the tissues of the holothurians (e.g chlorophyll a) should be used to determine their feeding selectivity.

Key words: Deep sea; carotenoids; Holothurian; reproduction; feeding selectivity; biomarkers.

Regional Index Terms: Porcupine Abyssal Plain, Northeast Atlantic Ocean

\section{List of Contents}

\section{Introduction}

\section{Materials and Methods}

2.1 Study site and sample collection

\subsection{Lipid analysis}


2.3 Pigment extraction and High Performance Liquid Chromatography (HPLC)

analysis

2.4 Quantification of pigments

2.5 Statistical analysis and comparison of pigment profiles

\section{Results}

3.1 Contamination of holothurian gut contents through lysis of gut wall cells

3.2 Phytopigments in the phytodetritus and sediment

3.3 Chlorophyll $a$ in holothurian gut contents

3.4 Species comparisons of ovarian carotenoid biochemistry - June 2004

3.5 Species comparisons of ovarian carotenoid biochemistry - July 2005

3.6 Temporal comparison of ovarian pigment biochemistry

\section{Discussion}

4.1 Phytopigments in the phytodetritus and sediment

4.2 Contamination of holothurian gut contents

4.3 Holothurian feeding selectivity - chlorophyll a in gut contents

4.4 Linking abyssal holothurian ovarian biochemistry with feeding guild, reproductive adaptation and food supply

\section{Conclusions}

\section{References}

\section{Introduction}

Holothurians dominate the abyssal sea floor in terms of abundance and biomass (Billett, 1991). They are key consumers of organic matter (OM) and bioturbators of surficial sediment (Turnewitsch et al., 2000). Shifts in the dominance of holothurian species can have a significant affect on the reworking of OM. During a population 
bloom of the holothurians Amperima rosea and Ellipinion molle at the Porcupine Abyssal Plain (PAP) (the 'Amperima Event') in the NE Atlantic between 1996 to 1999 (Billett et al., this volume; Billett et al., 2001), it was estimated that the sediment surface was re-worked by the benthic animals in less than six weeks, compared with a period of two and a half years prior to the holothurian bloom (Bett et al., 2001). Recently it has been shown that OM reaching the sea floor at the PAP may vary by up to an order of magnitude from year to year (Lampitt et al., this volume). Inter-annual variability in the quantity and quality of the flux may drive deep-sea benthic community shifts such as the 'Amperima Event' (Ginger et al., 2001; Kiriakoulakis et al., 2001; Hudson et al., 2003; Wigham et al., 2003a; Neto et al., 2006). Therefore, it is important to investigate how changes in both the amount and the composition of OM might affect deep-sea communities.

Phytopigments, which include carotenoids, chlorophyll and the degradation products of chlorophyll, have been used to indicate the degree of freshness of OM (Thiel et al., 1989) and to determine which phytoplankton species contribute to the export flux (Repeta \& Gagosian, 1987). Carotenoids can only be synthesised de novo by plants and some bacteria and fungi (Olson \& Owens, 1998). Some carotenoids are characteristic of specific algal groups (Jeffrey et al., 1997). Phytopigments have been used as biomarkers to determine the feeding ecology of deep-sea organisms (Billett et al., 1988; Duineveld et al., 1997; Witbaard et al., 2001; Hudson et al., 2003; Wigham et al., 2003a; Howell et al., 2004). Significant differences in the concentrations of pigments in the gut contents of abyssal and bathyal holothurians have been related to their feeding modes and the seasonal change in OM reaching the deep-sea floor (Billett et al., 1988; Hudson et al., 2003; Wigham et al., 2003a).

Carotenoids are required for deep-sea holothurian reproduction, but are in short supply in the abyssal ocean (Hudson et al., 2003; Wigham et al., 2003a). These compounds are assimilated from the phytodetritus that arrives at the sea floor from the overlying water column. Carotenoids stabilise proteins and membranes, and deactivate reactive chemical species such as free radicals that can damage DNA and unsaturated lipids in cells (Krinsky, 1994; Britton, 1995; Matsuno, 2001). Maternallyderived carotenoids in eggs protect the developing embryo from elevated reactive oxygen species released by the metabolism of fatty acids used for nourishment 
(Blount et al., 2000; Blount, 2004; Lotocka et al., 2004). Feeding experiments with shallow-water echinoderms have shown that carotenoids can enhance the colour of the roe to increase commercial viability, but more importantly, increase fecundity, larval maturation and survival (George \& Young, 1998; George et al., 2001; George \& Lawrence, 2002).

In the present study, phytopigments in the phytodetritus and sediment from the PAP were determined over two consecutive years and compared with holothurian gut contents and ovaries collected at the same time. The present study had two principal objectives:

1. To examine the link between the diet and ovarian biochemistry of deep-sea holothurians. Do changes in the quantity and composition of carotenoids available to abyssal holothurians affect their ovarian carotenoid biochemistry? If so, does the extent of this influence differ between species?

2. To examine the contamination of holothurian gut contents, by the leaching of compounds from the gut wall. It is important to determine whether the occurrence of specific biomarkers in deep-sea holothurian gut contents is evidence of selective feeding, or the result of contamination through gut wall cell lysis. 


\section{Materials and methods}

\subsection{Study site and sample collection}

Samples were collected at the PAP $\left(48^{\circ} 50^{\prime} \mathrm{N} 16^{\circ} 30^{\prime} \mathrm{W} ; \sim 4850 \mathrm{~m}\right.$ water depth, 270 $\mathrm{km}$ southwest of Ireland) in the northeast Atlantic Ocean (Billett \& Rice, 2001) (Figure 1). Holothurians were collected using an otter trawl (OTSB; Rice et al., 1990) during two cruises in June 2004 (RRS Charles Darwin cruise 158) and July 2005 (RRS Discovery cruise 296; Table 1). Eight different species were sampled. Amperima rosea was found rarely in the trawls recovered in July 2005. None of the specimens were in good condition and it was not possible to analyse this species in 2005. Immediately after recovery of the trawl, selected intact holothurians were transferred to pre-chilled water $\left(4^{\circ} \mathrm{C}\right)$ and taken to a constant temperature lab $\left(4^{\circ} \mathrm{C}\right)$ for dissection. Holothurians were dissected individually. Dissection tools were washed between specimens to eliminate cross contamination. Animals with burst guts were rejected (this was often the case for Molpadia blakei). Gut contents of specimens were obtained using the method of Ginger et al. (2001). Ovarian samples were also taken from each specimen. The samples were transferred to separate cryogenic micro tubes and frozen immediately $\left(-80^{\circ} \mathrm{C}\right)$.

Sediment samples were collected with either a Barnett-Watson multiple corer (Barnett et al., 1984; June 2004) or Bowers-Connelly mega-corer (Gage \& Bett, 2005; July 2005) (Table 1). On recovery, the cores were taken to a constant temperature laboratory $\left(4^{\circ} \mathrm{C}\right)$ for sectioning. Phytodetritus was present in depressions at the sediment surface on all four cores collected in June 2004 (only three of those cores were used for 0 to $5 \mathrm{~mm}$ sediment sections) and on all three cores in July 2005. This was carefully removed by pipette and frozen $\left(-80^{\circ} \mathrm{C}\right)$ separately from the top $5 \mathrm{~mm}$ of sediment. In addition, a deeper section of sediment (5 to $10 \mathrm{~mm}$ ) was taken for analysis from the cores sampled in July 2005.

\subsection{Lipid analysis}

The gut contents and muscle tissue of two abyssal holothurian species (Amperima rosea and Psychropotes longicauda) with contrasting gut structures were analysed to 
determine if the gut contents were contaminated with carotenoids derived from lysis of the gut wall cells. Sample preparation and analysis of tissue lipids followed the methods described by Neto et al. (2006). Gut content lipids were extracted in dichloromethane (DCM): methanol; 9:1 v/v by sonification (30 mins, x3). Known amounts of two internal standards $(5 \alpha(\mathrm{H})$-cholestane, $2.008 \mu \mathrm{g}$ and $5 \beta(\mathrm{H})$-cholanic acid, $3.015 \mu \mathrm{g}$, in DCM) were added before extraction. The extract was transferred to a pre-weighed vial, and the solvents were removed under a stream of $\mathrm{N}_{2}$. The extract was re-dissolved in DCM and dried by passing through a column of anhydrous sodium sulphate. The sample was then methylated using the method of Chambaz and Horning (1969) and silylated by treatment with bis-trimethylsilyltrifluoroacetamide $\left(60^{\circ} \mathrm{C} ; 2 \mathrm{~h}\right)$. Derivatised fractions were dissolved in DCM and analysed using a ThermoQuest CE gas chromatograph (Trace 2000 series) coupled with ThermoFinnigan TSQ-7000 mass spectrometer. The GC was fitted with an on-column injector and a capillary column (DB5-MS; $60 \mathrm{~m} \mathrm{x} 0.25 \mathrm{~mm}$ i.d., $0.10 \mu \mathrm{m}$ film thickness, $\mathrm{J} \& \mathrm{~W})$. The oven was held initially at $60^{\circ} \mathrm{C}$ for $1 \mathrm{~min}$, then heated from $60^{\circ} \mathrm{C}$ to $180^{\circ} \mathrm{C}$ at $12^{\circ} \mathrm{C} \mathrm{min}^{-1}$ and from $180^{\circ} \mathrm{C}$ to $315^{\circ} \mathrm{C}$ at $2.5^{\circ} \mathrm{C} \mathrm{min}^{-1}$, and held for 10 $\min$ at $315^{\circ} \mathrm{C}$. Helium was used as carrier gas at a constant flow $\left(1.6 \mathrm{~mL} \mathrm{~min}^{-1}\right.$, with vacuum compensation). A stream of air was used to cool the injector prior to, and for 1 min after each injection. Typical operating conditions for the mass spectrometer (MS) were: electron energy at $70 \mathrm{eV}$, scanning from 50 to 600 Thomsons, scan time of $1 \mathrm{~s}$, ion source temperature at $230^{\circ} \mathrm{C}$, interface temperature at $320^{\circ} \mathrm{C}$. Xcalibur Software (Version 1.0) was used to acquire and process the data. Fatty acids and sterols were identified by comparison of their relative retention times and mass spectra with those of authentic standards and/or by comparison with the literature. Concentrations of individual compounds were determined by comparison of their peak areas with those of the internal standards and were corrected after calculation of their relative response factors (Kiriakoulakis et al., 2004).

\subsection{Pigment extraction and High Performance Liquid Chromatography (HPLC) analysis}

Frozen phytodetritus, sediment, gut contents and ovarian tissue samples were lyophilised and weighed. Pigments were extracted in $3 \mathrm{~mL}$ (gut content and ovary) or 
$6 \mathrm{~mL}$ (sediment) 90\% HPLC grade acetone/water. Samples were ultrasonicated for 30 seconds then centrifuged for 10 mins at $3000 \mathrm{rpm}$. The extract was passed through a $(0.2 \mu \mathrm{m})$ Nyalo membrane filter (Gelman) prior to analysis.

Samples were transferred to amber vials and loaded into the chilled $\left(0^{\circ} \mathrm{C}\right)$ HPLC autosampler tray. Aliquots of sample $(500 \mu \mathrm{L})$ were mixed with $1 \mathrm{M}$ ammonium acetate $(500 \mu \mathrm{L})$ and $100 \mu \mathrm{L}$ of this mixture injected onto the HPLC column. Pigment samples were separated using ion paired reverse phase HPLC according to the method of Barlow et al. (1993) for 2004 samples or of Barlow et al. (1997) for 2005 samples, which improved the resolution of the carotenoids diadinoxanthin, alloxanthin, diatoxanthin and zeaxanthin, which elute closely on the chromatogram (aiding rapid peak identification).

The HPLC was controlled by the ChromQuest software system. It consisted of either a Perkin Elmer C18 column (Barlow et al., 1993) or Perkin Elmer C8 column (Barlow et al., 1997), Thermoseparation HPLC system with an online vacuum degasser, a dual solvent pump (P2000), autosampler (AS3000), a UV photodiode array detector (UV6000), and a Spectra System fluorescence detector (FL3000). Chlorophylls and carotenoids were detected by absorbance at $440 \mathrm{~nm}$; pheopigments were monitored with the fluorescence detector using excitation and emission wavelengths of 410 and $670 \mathrm{~nm}$, respectively. Pigments were identified by comparison of relative retention times with pigment standards. Supporting identification was gained by comparison of spectral data with known standards as well as by reference to the Jeffrey et al. (1997).

\subsection{Quantification of pigments}

Pigment concentrations ( $\mu \mathrm{g} \mathrm{g}^{-1}$ dry weight sediment/tissue sample) were calculated as follows:

$$
C=\left(\left(A_{p} V_{e x} 1000\right) /\left(R_{f} W B V_{i n j}\right)\right) / 100
$$

Where $A_{p}$ is the peak area detected at $440 \mathrm{~nm}, V_{e x}$ is the extract volume in $\mathrm{ml}, \mathrm{R}_{f}$ is the response factor, $\mathrm{W}$ is the dry weight of sediment in grams, $\mathrm{B}$ is the buffer dilution 
factor (0.5) and $V_{i n j}$ is the volume of extract injected $(\mu 1)$. Response factors for each of the pigments were calculated by plotting concentrations of the standards against peak area. Reproducibility of the analytical technique was better than $\pm 10 \%$ and the analytical precision $< \pm 5 \%$.

\subsection{Statistical analysis and comparison of pigment profiles}

The contribution of holothurian-derived $\Delta^{7}$ sterols to holothurian gut contents was compared statistically to the muscle tissue (t-test) to assess the degree of contamination of the gut contents through lysis of gut wall cells. Gut content chlorophyll $a$ concentration ( $\mu \mathrm{gDW}^{-1}$ ) was analysed for between year differences. If variables had a normal distribution and a homogenous variance, ANOVA was applied to determine if there was any within year statistical variation in species gut chlorophyll $a$ concentration. Ovarian carotenoid concentrations were analysed for between year differences. Statistical analyses of pigment concentrations were implemented with Minitab software (Version 12.21). Data were tested for their distribution using the Ryan-Joiner test. The means of normally distributed data were compared using the t-test; the Mann-Whitney test was applied to non-normally distributed data to compare their medians. Carotenoid concentrations in the ovaries of the holothurians were transformed to their percentage contributions to the total carotenoid concentration in each sample, in order to diagnose differences in pigment biochemistry between species. This approach removed differences that might be related to the pigment load in each specimen. Direct between species and between year carotenoid percentage contribution comparisons were made using ANOSIM and multivariate statistical analysis on square-root transformed data. The PRIMER 6 software package (Clarke \& Warwick, 1994) was used.

\section{Results}

\subsection{Contamination of holothurian gut contents through lysis of gut wall cells}

Amperima rosea and Psychropotes longicauda gut content samples were both contaminated with holothurian-derived lipids, namely $C_{23: 1}$ and $C_{24: 1}$ and $\Delta^{7}$ sterol, choles-7-en-3 $\beta$-ol (Ginger et al., 2000; Ginger et al., 2001). The contribution of 
choles-7-en-3 $\beta$-ol to A. rosea gut content samples was not statistically different from its contribution to the muscle tissue $(\mathrm{t}(6)=0.3, \mathrm{P}>0.05)$. The contribution of choles-7en-3 $\beta$-ol to the gut contents of $P$. longicauda is significantly lower $(\mathrm{t}(25)=10.13$, $\mathrm{P}<0.05$ ) than in the muscle tissue.

\subsection{Phytopigments in the phytodetritus and sediment}

Ten pigments were identified in the phytodetritus and sediments sampled in June 2004, and twelve in July 2005 (Figure 2). The phytodetritus had consistently higher concentrations of phytopigments compared to the top $5 \mathrm{~mm}$ and 5 to $10 \mathrm{~mm}$ sections of the sediment. Phaeophorbide $a$ was the dominant pigment in the phytodetritus in both years. In June 2004, chlorophyll $c 2$, diatoxanthin and $\beta$-carotene were present in the phytodetritus, but were absent in surficial sediment samples (0 to $5 \mathrm{~mm}$ ). Diatoxanthin and zeaxanthin were present in the phytodetritus but not the sediment in 2005 (Figure 2). Chlorophyll c2 was present in the phytodetritus in June 2004 but not July 2005. Violaxanthin, 19'-butanoyloxyfucoxanthin and 19'hexanoyloxyfucoxanthin were present in the phytodetritus and surficial sediment in 2005 but absent in June 2004. In the phytodetritus, fucoxanthin ( $\mathrm{t}(5)=9.17, \mathrm{P}<0.05)$, alloxanthin $(\mathrm{t}(5)=3.85, \mathrm{P}<0.05)$, diatoxanthin $(\mathrm{t}(5)=4.99, \mathrm{P}<0.05)$, zeaxanthin $(\mathrm{t}(5)$ $=24.84, \mathrm{P}<0.05)$, chlorophyll $a(\mathrm{t}(5)=12.64, \mathrm{P}<0.05)$ and $\beta$-carotene $(\mathrm{t}(5)=6.21$, $\mathrm{P}<0.05)$ were all found in significantly greater concentrations in 2004 samples.

Nine pigments co-occurred in the top $5 \mathrm{~mm}$ sediment from 2004 and 2005. All were found in higher concentrations in 2004 (Figure 2). Fucoxanthin $(\mathrm{t}(4)=6.6, \mathrm{P}<0.05)$ and chlorophyll $a(\mathrm{t}(4)=7.28, \mathrm{P}<0.05)$ were found in significantly greater concentrations in the sediment sampled in 2004. Chlorophyll $a$, an indicator of the contribution of fresh organic matter, was present in concentrations of 25 and $3 \mathrm{x}$ greater in the phytodetritus than in the surficial sediment in June 2004 and July 2005, respectively. The ratio of chlorophyll $a$ to phaeophorbide can be used as an indicator of freshness of phytodetrital material; a higher ratio indicates a greater degree of freshness (Thiel et al., 1989). The phytodetritus in 2004 had a chlorophyll $a$ : phaeophorbide $a$ ratio of 0.67 (S.D \pm 0.15 ) compared to 0.29 (S.D. \pm 0.49 ) in 2005. There was no significant difference $(\mathrm{t}(5)=1.84, \mathrm{P}>0.05)$ in the chlorophyll $a$ to phaeophorbide $a$ ratio between the years because of the high variability in 2005 . 


\subsection{Chlorophyll a in holothurian gut contents}

All species had higher concentrations of chlorophyll $a\left(\mu \mathrm{g} \mathrm{gDW}^{-1}\right)$ in their gut contents than in either the sediment or phytodetritus (Figure 2 and 3), with the exception of M. blakei. Chlorophyll $a$ was absent in the gut contents of M. blakei. Chlorophyll $a$ was absent in ten of the fourteen samples of $A$. rosea gut contents. The average gut content chlorophyll $a$ concentration was $1.19 \mu \mathrm{gDW}^{-1}$ when all A. rosea samples were included. The average concentration of $A$. rosea specimens that contained chlorophyll $a$ was $4.16 \mu \mathrm{g} \mathrm{gDW}^{-1}$; this is greater than the average chlorophyll $a$ gut content concentration of the other species sampled (Figure 3).

Chlorophyll $a$ concentrations in the gut contents of $O$. mutabilis and Psychropotes longicauda were significantly greater in 2004 than in $2005(\mathrm{t}(12)=3.58, \mathrm{P}<0.05 ; \mathrm{t}(11)$ $=2.19, \mathrm{P}<0.05$, respectively). There was no significant between year difference in chlorophyll a gut content concentration in Paroriza prouhoi $(\mathrm{t}(5)=0, \mathrm{P}>0.05)$. All species sampled in 2005 (excluding $M$. blakei) showed no significant difference $\left(F_{4,25}\right.$ $=1.42, \mathrm{P}>0.05)$ in their average gut content chlorophyll $a$ concentration.

\subsection{Species comparisons of ovarian carotenoid biochemistry - June 2004}

The concentrations $\left(\mu \mathrm{g} \mathrm{gDW}^{-1}\right)$ of ovarian carotenoids varied considerably between species. For example, A. rosea had pigment concentrations an order of magnitude greater than O. mutabilis and Peniagone diaphana, and two orders of magnitude greater than Psychropotes longicauda and Paroriza prouhoi (Figure 4). Variability of the pigment concentrations in the ovary was high. Echinenone and zeaxanthin were found in high concentrations in the ovary (contributing $>22 \%$ and $>26 \%$ to the total respectively) of $A$. rosea (Figure 4). $\beta$-carotene was found in the greatest concentration in the ovary (contributing $>56 \%$ to the total) of $O$. mutabilis (Figure 4 ).

Multi Dimensional Scaling (MDS) ordination of the square root transformed pigment percentage contributions of the ovary samples shows some species clustering (Figure 5a). Amperima rosea shows the tightest species-specific clustering, indicating the specimens had a very consistent biochemical profile. The spread of $O$. mutabilis ovary 
samples from the centre to the top right reflected the relative contribution of $\beta$ carotene to the total pigment load (Figure 5a); other carotenoids showed little variation in concentration (Figure 4). The contribution of $\beta$-carotene to the total pigment load in the ovarian samples ranged from $30 \%$ to $70 \%$. Paroriza prouhoi ovarian samples are spread from top right to centre because of the presence or absence of alloxanthin and the increasing contribution of diadinoxanthin (Figure 5a).

\subsection{Species comparisons of ovarian carotenoid biochemistry - July 2005}

Oneirophanta mutabilis had the highest concentration of carotenoids $\left(\mu \mathrm{gDW}^{-1}\right)$ in its ovarian samples in comparison to the other holothurians sampled in July 2005 (Figure 4). 19'-butanoyloxyfucoxanthin and 19'-hexanoyloxyfucoxanthin were present in the ovaries of all species sampled, with the exception of 19'hexanoyloxyfucoxanthin, which was not found in the ovaries of M. blakei and Pseudostichopus aemulatus (Figure 4). Both 19'-butanoyloxyfucoxanthin and 19'hexanoyloxyfucoxanthin were found in relatively lower concentrations compared to the other carotenoids present in the ovaries of O. mutabilis.

Species specific clustering was observed for O. mutabilis, Psychropotes longicauda and Paroriza prouhoi on the MDS ordination plot of ovarian samples. The clusters of these three species are also very close to each other (Figure 5b). Molpadia blakei shows species specific clustering with the exception of one sample, which contained no 19'-butanoyloxyfucoxanthin. Pseudostichopus villosus shows ovarian species specific clustering for four samples, but not for three other samples. P. aemulatus shows some species specific clustering for two samples but one sample, containing only $\beta$-carotene, is situated to the bottom right of the plot.

\subsection{Temporal comparison of ovarian pigment biochemistry}

Oneirophanta mutabilis, Psychropotes longicauda and Paroriza prouhoi were collected in both June 2004 and in July 2005. Average concentrations of carotenoids in the ovaries of Psychropotes longicauda were greater in 2004 with the exception of 19'-butanoyloxyfucoxanthin and 19'-hexanoyloxyfucoxanthin (absent from samples taken in 2004) (Figure 4). Average concentrations of carotenoids in O. mutabilis 
ovaries were similar between years with the exception of $\beta$-carotene, which was higher in 2004. Paroriza prouhoi 2005 ovarian samples contained higher average concentrations of all carotenoids, with the exception of zeaxanthin, canthaxanthin and echinenone, which were higher in 2004 (Figure 4).

MDS ordination of the pigment percentage contribution in the ovaries of the three species sampled in both years show close clustering between years for O. mutabilis samples; the slight between year separation was caused by the small percentage (together less than 5\%) contribution of 19'-butanoyloxyfucoxanthin and 19'hexanoyloxyfucoxanthin in the samples taken in 2005 (Figure 6). The spread of $O$. mutabilis samples on the MDS plot is attributed to the varying contribution of $\beta$ carotene. ANOSIM analysis indicated O. mutabilis samples showed no difference in composition between the years, but the R-statistic was not significant (ANOSIM R = $0.143, \mathrm{P}>0.05$ ) because of the variability of the PAP 2004 samples. This was caused by the different percentage contribution of $\beta$-carotene (ranging from 30 to $80 \%$ ). Psychropotes longicauda and Paroriza prouhoi samples were significantly different in their ovarian pigment biochemistry between years (ANOSIM R $=0.891$ (Psychropotes longicauda) $\mathrm{R}=0.877$ (Paroriza prouhoi), $\mathrm{P}<0.05$ ). Differences between the years for Psychropotes longicauda and Paroriza prouhoi can be attributed to the high percentage contribution of 19'-butanoyloxyfucoxanthin and 19'hexanoyloxyfucoxanthin and the decreased percentage contribution and concentration of zeaxanthin in their ovaries (Figure 4).

\section{Discussion}

The importance of the composition as well as the amount of the OM reaching the deep-sea floor, and its influence on the benthic community, are becoming apparent (Billett et al., this volume; Billett et al., 2001; Smith et al., 2001; Wigham et al., 2003a; Hudson et al., 2004; Ruhl \& Smith, 2004; Neto et al., 2006). The timing and make-up of the phytoplankton bloom, zooplankton interactions (repackaging and recycling) and the physical dynamics of the water column can all affect the quality and quantity of the seasonal POM flux to the sea floor (Turner, 2002). Upper ocean phyto- and pico-plankton community structure changes temporally over the PAP 
(Gibb et al., 2000; Zubkov et al., 2000), which in turn affects the quantity and composition of carotenoids in the flux of OM (Smythe-Wright et al., this volume).

\subsection{Phytopigments in the phytodetritus and sediment}

The present study supports previous observations that in many oceanic areas there is not a consistent food supply to the deep-sea benthos; compounds essential to the deepsea benthic community vary temporally in their amount and availability within years and between years (Santos et al., 1994; Danovaro et al., 2001; Kiriakoulakis et al., 2001; Witbaard et al., 2001; Neto et al., 2006). 19'-butanoyloxyfucoxanthin, 19'hexanoyloxyfucoxanthin and violaxanthin were present in the phytodetritus and sediment in July 2005, but were absent in June 2004 (Figure 2a and b), suggesting different phytoplankton groups contributed to the flux of OM to the sea floor. 19'butanoyloxyfucoxanthin and 19'-hexanoyloxyfucoxanthin are biomarkers of prymnesiophytes and some dinoflagellates; violaxanthin is considered a biomarker for eustigmatophytes (small pico-nano phytoplankton) (Jeffrey et al., 1997).

Temporal variability in the freshness of the phytodetritus was also apparent; greater chlorophyll $a$ concentration and chlorophyll $a$ to phaeophorbide $a$ ratios in the phytodetritus and sediment in June 2004 (ratio of 0.67) indicate the material at the sea floor was fresher than that sampled in July 2005 (ratio of 0.29). A similar chlorophyll $a$ to phaeophorbide $a$ ratio of 0.23 has been recorded at the PAP in July 1997 and a higher ratio of 1.33 was recorded in September 1996, after a large flux of relatively fresh phytodetritus (Witbaard et al., 2000). High flux events are linked to fresher OM reaching the seabed at the PAP (Salter, 2007). Interannual differences in the mass flux of material (3000 m sediment trap; Lampitt et al., this volume; Lampitt et al., 2001) may explain the differences in the chlorophyll concentrations and chlorophyll $a$ to phaeophorbide ratios observed in the present study. The timing of the flux to the seafloor at the PAP was late May/early June in 2004 and early May in 2005 (Lampitt et al., this volume). Mass flux of material in June 2004 was between 150-200 $\mathrm{mg} \mathrm{m}^{-2} \mathrm{~d}^{-1}$, over double that of $20-50 \mathrm{mg} \mathrm{m}^{-2} \mathrm{~d}^{-1}$ in June and July 2005 (Lampitt et al., this volume). Spatial variability in the freshness of the phytodetritus was also more pronounced in 2005 than in 2004, as indicated by the high variability (greater than the mean) in the chlorophyll $a$ to phaeophorbide $a$ ratio in 2005. 
Sediment chlorophyll $a$ concentrations have been recorded intermittently at the PAP. In samples collected between September 1996 to September 1998 (Witbaard et al., 2001) chlorophyll concentrations in the top $1 \mathrm{~mm}$ of sediment ranged from 0.0086 to $0.0326 \mu \mathrm{g} \mathrm{gDW}^{-1}$ (converted from $\mathrm{ng} \mathrm{cm}^{-3}$ by Wigham, 2002). Hudson (2004) reported a chlorophyll $a$ concentration of $0.12 \mu \mathrm{g} \mathrm{gDW}^{-1}$ in October 2002 in the top 1 $\mathrm{mm}$ sediment. The present study observed concentrations of $0.052 \mu \mathrm{g} \mathrm{gDW}^{-1} \pm 0.046$ (June 2004) and $0.028 \mu \mathrm{g} \mathrm{gDW}^{-1} \pm 0.01$ (July 2005) in the top $5 \mathrm{~mm}$ sediment. The lower sediment chlorophyll concentrations at the PAP in 1996, 1998 (Witbaard et al., 2001), 2004 and 2005 (present study) in comparison to October 2002 (Hudson, 2004) and other abyssal sites (Riaux-Gobin et al., 1997; de Wilde et al., 1998; Lee et al., 2000) may be attributed to reduced supply, but also to the benthic fauna. Bett et al. (2001) showed that megabenthic reworking rates can vary from weeks to years depending on the community structure. This, in turn, will affect the chlorophyll concentration in the sediment.

\subsection{Contamination of holothurian gut contents}

Comparisons between the gut contents and ovarian carotenoid profiles of deep-sea holothurians led Wigham et al. (2003a) and Hudson et al. (2003) to infer some species feed selectively on $\mathrm{OM}$ enriched in specific carotenoids required for their reproduction. This selectivity would presumably give them a competitive advantage when the supply of critical compounds was favourable. However, Ginger et al. (2001) reported that the gut contents of Oneirophanta mutabilis collected from the PAP were contaminated with holothurian-derived lipids. The authors suggested this contamination derived from unregulated lipolysis of phospholipid within the digestive tissue resulting from the death of organisms on recovery. Smith (2008) has shown carotenoids are present in the gut walls of abyssal holothurians in higher concentrations $\left(\mu \mathrm{g} \mathrm{gDW}^{-1}\right)$ relative to the ovaries. Carotenoid profiles of the gut contents and ovary of $A$. rosea are very similar (Wigham et al., 2003a); this species has a fragile gut, which makes it difficult to sample without contamination from the gut wall (pers. obs.). Psychropotes longicauda, in contrast, has a large compact gut, which facilitates easier sampling of the gut contents away from the gut wall. This 
species has differing gut content and ovarian carotenoid profiles (Wigham et al., 2003a).

The abundance of the holothurian-derived $\Delta^{7}$ sterol choles-7-en-3 $\beta$-ol, and fatty acids $\mathrm{C}_{23: 1}$ and $\mathrm{C}_{24: 1}$ in $A$. rosea gut contents suggests that high concentrations of carotenoids in the gut contents of A. rosea (Wigham et al., 2003a) are likely to have been derived from their gut walls following cell lysis during recovery of the animals from the sea floor. Contamination of gut contents was also supported by the presence of canthaxanthin in all species and by echinenone in some species (A. rosea, Peniagone diaphana and Paroriza prouhoi). These pigments were not found in the surficial sediment or phytodetritus, but were present in the gut wall (Figure 2; Smith, 2008). Therefore, the use of biomarkers in gut contents, which are also present in the organisms tissues, to determine feeding selectivity in deep-sea organisms (Hudson et al., 2003; Wigham et al., 2003a; Howell et al., 2004) should be used with caution. This also applies to species such as Psychropotes longicauda, which have large, compact guts; the concentration of holothurian-derived choles-7-en-3 $\beta$-ol may be significantly less than found in the muscle tissue, but the presence of this compound and the holothurian-derived $\mathrm{C}_{23: 1}$ and $\mathrm{C}_{24: 1}$ fatty acids in the gut contents discounts the use of certain compounds as biomarkers for feeding ecology. Selectivity - in terms of selecting 'fresh' material - can be inferred, however, from biomarkers in the gut contents that are not assimilated by the organisms (e.g. chlorophyll $a$ ). Furthermore, the variability in biomarker distributions in tissue samples is related to the feeding mode of the species, temporal variability biomarker of supply (Neto et al., 2006) and variability in the decay rate of each biomarker (i.e. those that persist in the sediment for longer will be available to the benthic fauna for longer).

\subsection{Holothurian feeding selectivity - chlorophyll a in gut contents}

Interspecific differences in gut content chlorophyll a concentrations (Figure 3) suggest some species were more capable of utilising fresh organic matter than others. The contrast between the absence and high concentration of chlorophyll $a$ in A. rosea gut contents (Figure 3) suggests this species selectively feeds on the freshest material when it can find it. Between 1997-1998 at the PAP, when abundance of Amperima rosea was high, the species exhibited a high average tracking rate (area of seabed 
moved over by each individual megabenthic organism) of $110 \mathrm{~cm}^{2} \mathrm{~m}^{-1} \mathrm{~d}^{-1}$, which was 20 times greater than the other holothurians during the same period (Bett et al., 2001). Stable isotope and microscope analysis of $A$. rosea gut contents have shown that it selects for fresh material (Iken et al., 2001). Amperima rosea gut content chlorophyll $a$ concentrations were $45.94 \mu \mathrm{g} \mathrm{gDW}^{-1}$ (S.D. \pm 40.41 ) and $30.85 \mu \mathrm{g} \mathrm{gDW} \mathrm{gW}^{-1}$ (S.D. \pm 3.63) in October 2000 and March 2002, respectively (Wigham et al., 2003a). These concentrations were lower in October 2002 (Hudson, 2004) and June 2004 (present study) with values of $3.45 \mu \mathrm{g} \mathrm{gDW}^{-1}$ (S.D. \pm 3.23) and 1.18 (S.D. \pm 2.01 ), respectively. The lower concentrations in more recent years (and the absence of chlorophyll $a$ from some specimens in June 2004) may be a function of the amount of fresh phytodetritus at the sea floor at the PAP at the time of sampling. Although there is lack of comparable sediment chlorophyll $a$ concentration data to show this, differences in the mass flux of OM to the seafloor between 2000 and 2005 are apparent. In particular, a relatively large flux of material in 2001 in comparison with 2003-2005 (Lampitt et al., this volume), suggests OM flux was higher in the years A. rosea had enhanced gut chlorophyll $a$ concentration.

Peniagone diaphana and O. mutabilis also show greater selection for fresh material, compared with Psychropotes longicauda and Paroriza prouhoi in June 2004 (Figure 3). These differences probably reflect their feeding modes. Oneirophanta mutabilis is "a picker", using its digitate tentacles to transfer sediment to its mouth. It also has high rate of locomotion for a holothurian (Roberts et al., 2000). Peniagone diaphana is a benthopelagic holothurian but feeds at the sediment surface (Billett, 1991) on fresh OM (Iken et al., 2001). Psychropotes longicauda also feeds on the sediment surface, but its peltate tentacle structure (sweeping sediment into the mouth) suggests it is less selective (Roberts et al., 2000). This is supported by it having body tissue relatively enriched in the heavy isotope $\sigma^{15} \mathrm{~N}$, suggesting it feeds on more refractory material (Iken et al., 2001). Paroriza prouhoi has similarly enriched isotopic $\sigma^{15} \mathrm{~N}$ values to that of Molpadia blakei (a known subsurface feeder (Tyler et al., 1987), with no detectable chlorophyll $a$ in its gut; Figure 3). This indicates they feed on the same refractory material (Iken et al., 2001). Direct observations of Paroriza pallens have shown it moves very slowly through the sediment (Paul Tyler, pers. obs.). 
Fresher and less patchy phytodetritus in 2004 may explain why Oneirophanta mutabilis and Psychropotes longicauda had greater chlorophyll a gut content concentrations in 2004 than in 2005. Oneirophanta mutabilis gut content chlorophyll $a$ concentration was not significantly different to $P$. longicauda in 2005 suggesting they had similar encounter rates with fresh material, despite the greater selectivity by O. mutabilis. The concentration of chlorophyll $a$ in the gut contents of $O$. mutabilis has previously been shown to correlate with that of the top $1 \mathrm{~mm}$ of sediment at PAP (Witbaard et al., 2001). The present study also supports the suggestion of Neto et al. (2006) that $O$. mutabilis feeds on the same material as $P$. longicauda when fresh organic matter is scarce. Concentrations of chlorophyll $a$ in the gut contents of Paroriza prouhoi were not significantly different between years, suggesting it is not a selective feeder; Paroriza spp. gut contents have previously been shown not to vary seasonally (Khripounoff \& Sibuet, 1980; Billett et al., 1988). Chlorophyll a concentration in the top $5 \mathrm{~mm}$ sediment was only slightly higher in 2004 than in 2005 , but showed high variability; this may have led to the similar between-year P. prouhoi gut content chlorophyll a concentrations. Pseudostichopus aemulatus had slightly higher, but variable gut content chlorophyll $a$ concentrations relative to its congener $P$. villosus and other holothurian species sampled in 2005, although this is not statistically significant. Pseudostichopus villosus has a feeding mode that 'ploughs' slowly through the sediment, probably ingesting sediments from $1-2 \mathrm{~cm}$ depth (Billett, 1991; Moore \& Roberts, 1994). Therefore, P. villosus will exploit carotenoid-depleted sediment (Figure 2b). Pseudostichopus aemulatus, however, is smaller than $P$. villosus and has a different foraging behaviour, feeding on the superficial sediment rich in OM (Billett et al., 1988). The relatively low concentrations of chlorophyll $a$ in the phytodetritus and sediment in 2005 would have led to a lower encounter rate with fresh material.

\subsection{Linking abyssal holothurian ovarian biochemistry with feeding guild, reproductive adaptation and food supply}

Large interspecific differences in the concentrations of carotenoids in holothurian ovaries may be attributed to their reproductive adaptation. Survival of post-larvae is an important factor in response to the seasonal flux of phytodetritus, contributing to population structure and density (Wigham et al., 2003b). Amperima rosea has the 
highest carotenoid load of all the species sampled, followed by O. mutabilis and $P$. diaphana. To obtain the highest dietary concentration of carotenoids it would be beneficial to feed on the freshest organic matter - as supported by the high chlorophyll $a$ concentration found in some A. rosea gut content samples. Experiments on shallow water echinoderms have shown that the larvae of adults fed carotenoids were larger throughout development, developed faster and had higher survival rates (Tsushima et al., 1997; George et al., 2001; George \& Lawrence, 2002). Assimilating a high carotenoid load into its ovaries may give $A$. rosea an additional reproductive advantage. Carotenoids reduce the harmful effects of reactive oxygen species given off during the rapid metabolism of lipids in the egg, increasing larval survival. Amperima rosea reaches maturity at a small size and has a high fecundity (Wigham et al., 2003b). Therefore, A. rosea may produce many viable offspring during favourable conditions, leaving a large cohort either to exploit the remaining favourable $\mathrm{OM}$, or to wait until the next favourable conditions occur. Population explosions of opportunistic species have been shown to affect other species. During the 'Amperima Event' $P$. diaphana almost disappeared and Psychropotes longicauda and O. mutabilis decreased in size (Billett et al., this volume; Billett et al., 2001). The fecundity of $O$. mutabilis also decreased at this time (Ramirez-Llodra et al., 2005).

Qualitative comparisons of ovarian carotenoid profiles in deep-sea holothurians indicate intraspecies profiles are similar but interspecific profiles are different (Hudson et al., 2003; Wigham et al., 2003a; present study). Resource partitioning between species may explain interspecific differences in ovarian carotenoid biochemistry; many deep-sea holothurians show niche differentiation with species using different methods for exploiting food resources (Billett, 1991). Temporal variations in abyssal holothurian fatty acid composition have been related to the varying reproductive patterns of species (Hudson et al., 2004) and also in response to a changing supply of lipids, dependent on the feeding guild of the species (Neto et al., 2006).

Tight species-specific clustering of A. rosea ovarian samples shown on the June 2004 MDS ordination plot (Figure 5a) reflects the similarity of the carotenoid profiles. This suggests selectivity and/or requirement for specific carotenoids, particularly zeaxanthin which constitutes $>28 \%$ of the total tissue pigment load. The carotenoid 
profiles of $O$. mutabilis and Peniagone diaphana were less consistent than in A. rosea. The contribution of only one or two carotenoids, ( $\beta$-carotene in O. mutabilis, $\beta$ carotene and echinenone in $P$. diaphana) caused the differences between the ovarian samples (Figure 5a). Psychropotes longicauda and Paroriza prouhoi showed less species specific clustering in the ovarian samples in 2004 because of inconsistent carotenoid profiles between samples (Figure 5a). A change in the relative contributions of more than one carotenoid accounted for the spread of samples on the MDS ordination plot (Figure 5a), suggesting Psychropotes longicauda and Paroriza prouhoi are not selective in their carotenoid biochemistry.

The occurrence of 19'-butanoyloxyfucoxanthin and 19'-hexanoyloxyfucoxanthin in the phytodetritus, sediment and ovaries of abyssal holothurians sampled in 2005, and the lower zeaxanthin concentration in the phytodetritus and sediment in 2005 and its concurrent lower concentration in the ovaries of Psychropotes longicauda and Paroriza prouhoi, suggests the composition of OM does exert an influence on the abyssal holothurians biochemistry. The extent of this influence appears to differ between species. Between year comparisons show Psychropotes longicauda and Paroriza prouhoi appear not to discriminate between carotenoids during feeding and assimilation into body tissues. The feeding guild of these species may dictate this; selectivity for specific carotenoids does not occur, as the compounds in the sediment fractions on which they feed are not abundant and are temporally variable. In contrast, O. mutabilis shows greater temporal consistency in its ovarian carotenoid biochemical profile. The pigment profiles in the ovaries of this species are not different between years. The ability of $O$. mutabilis to exploit fresher $\mathrm{OM}$, containing greater concentrations and types of carotenoids, may allow for compound specific selectivity. This inference is also supported by the consistent biochemical profile of $A$. rosea, which feeds on the freshest OM, and the inconsistent profiles of Pseudostichopus aemulatus and $P$. villosus, which feed on deeper sediments presumably assimilating carotenoids with less selectivity. Wigham et al. (2003a) suggested that the supply of certain carotenoids may favour particular species. This was based on the occurrence of specific carotenoids in both the gut contents and ovaries, which would infer selective feeding, e.g. zeaxanthin in A. rosea. Although the present study shows that zeaxanthin in $A$. rosea gut content may arise from the lysis of the gut wall, the hypothesis of Wigham et al. (2003a) still stands because of the consistent 
biochemical profile in $A$. rosea ovarian tissues and its requirement for zeaxanthin in large concentrations. In addition, the enhanced supply or availability of $\beta$-carotene may favour $O$. mutabilis; $\beta$-carotene is consistently the dominant carotenoid in $O$. mutabilis ovarian tissue.

\section{Conclusions}

The composition and amount of OM reaching the PAP varies both temporally and spatially. This can affect the diet of some abyssal holothurian species, depending on their feeding guild. The ovarian carotenoid biochemistry of the abyssal holothurians is a complex function of the supply, feeding guild and reproductive adaptation of each species. Amperima rosea, Peniagone diaphana and Oneirophanta mutabilis display consistent ovarian carotenoid profiles and have higher concentrations of carotenoids in their ovaries than do other species. Favourable conditions may give these species a reproductive advantage, supplying specific carotenoids required for their reproduction. Enhanced carotenoid concentrations in these species may be a reproductive adaptation to increase larval survival.

Contamination of gut contents by the lysis of gut wall tissue has been shown in two holothurians with differing gut structures. The use of biomarkers to infer the feeding ecology of deep-sea megafauna should be used with caution; the occurrence of holothurian-derived compounds in the gut contents should always be investigated.

This study suggests that diet and reproduction in deep-sea holothurians are intimately linked. Recent climate change studies show plankton can be affected on global and longer temporal scales (Richardson \& Schoeman, 2004). Changes in upper ocean biogeochemistry, altering the quality and quantity of organic matter reaching the deep-sea floor may control holothurian reproductive output and favour certain species. This can have a subsequent effect on the surrounding biota, as seen during the 'Amperima Event' at the Porcupine Abyssal Plain (Billett et al., this volume; Billett et al., 2001), leading to changes in sediment reworking rates (Bett et al., 2001) and probably affecting carbon burial.

\section{Acknowledgements}


The authors would like to thank the officers, crew and scientists aboard RRS Charles Darwin 158 and RRS Discovery cruise 296 for their help and assistance at sea. In particular, the authors would like to thank Ian Hudson for sample collection on the RRS CD158 research cruise. T. Smith is funded by NERC studentship NER/S/A/2004/12633. Brian Bett kindly provided the map of the PAP observatory.

The paper makes a contribution to the Census of Marine Life (CoML) field project on the Census of the Diversity of Abyssal Marine Life (CeDAMAR), the EU Network of Excellence on Marine Biodiversity and Ecosystem (MarBEF) responsive mode project on Deep-sea and Extreme Environments Patterns of Species and Ecosystem Time-Series (DEEPSETS), and the UK Natural Environment Research Council strategic research project "Oceans 2025".

\section{References}

Barlow, R.G., Cummings, D.G., Gibb, S., 1997. Improved resolution of mono- and divinyl chlorophylls $a$ and $b$ and zeaxanthin and lutein in phytoplankton extracts using reverse phase C-8 HPLC. Marine Ecology Progress Series 161, 303-307.

Barlow, R.G., Mantoura, R.F.C., Gough, M.A., Fileman, T.W., 1993. Pigment signatures of the phytoplankton composition in the northeastern Atlantic during the 1990 spring bloom. Deep-Sea Research Part II 40 (1/2), 459-477.

Barnett, P.R.O. 1998-1999. The core issue? 30th Annual Report, 1999-2000. University Marine Biological Station, Millport: 14.

Barnett, P.R.O., Watson, J., Connelly, D., 1984. A multiple corer for taking virtually undisturbed samples from shelf, bathyal and abyssal sediments. Oceanologica Acta 7, 399-408.

Bett, B.J., Malzone, M.G., Narayanaswamy, B.E., Wigham, B.D., 2001. Temporal variability in phytodetritus and megabenthic activity at the seabed in the deep Northeast Atlantic. Progress in Oceanography 50, 349-368.

Billett, D.S.M., 1991. Deep-sea holothurians. Oceanography and Marine Biology: an Annual Review 29, 259-317.

Billett, D.S.M., Bett, B.J., Reid, W.D.K., Boorman, B., Priede, I.G., Long-term change in the abyssal NE Atlantic: The 'Amperima Event' revisited. Deep-Sea Research Part II this volume. 
Billett, D.S.M., Bett, B.J., Rice, A.L., Thurston, M.H., Galéron, J., Sibuet, M., Wolff, G.A., 2001. Long-term change in the megabenthos of the Porcupine Abyssal Plain (NE Atlantic). Progress in Oceanography 50, 352-348.

Billett, D.S.M., Llewellyn, C., Watson, J., 1988. Are deep-sea holothurians selective feeders? In: Burke, R.D., Mladenov, P.V., Lambert, P. and Parsley, R.L. (Eds). Echinoderm Biology. Balkema, Rotterdam, pp. 154-162.

Billett, D.S.M., Rice, A.L., 2001. The BENGAL programme: introduction and overview. Progress in Oceanography 50, 13-25.

Blount, J.D., 2004. Carotenoids and life-history evolution in animals. Archives of Biochemistry and Biophysics 430, 10-15.

Blount, J.D., Houston, D.C., Pape Moller, A., 2000. Why egg yolk is yellow. Trends in Ecology and Evolution 15 (2), 47-49.

Britton, G., 1995. Structure and properties of carotenoids in relation to function. The Federation of American Societies for Experimental Biology Journal 9 (15), 151-1558.

Chambaz, E., Horning, E.C., 1969. Conversion of steroids to trimethylsilyl derivatives for gas phase analytical studies: reactions of silylating reagents. Analytical Biochemistry 30, 7-24.

Clarke, K.R., Warwick, R.M., 1994. Change in marine communities: an approach to statistical analysis and interpretation. Plymouth Marine Laboratory, Plymouth.

Danovaro, R., Dell'Anno, A., Fabiano, M., 2001. Bioavailability of organic matter in the sediments of the Porcupine Abyssal Plain, northeastern Atlantic. Marine Ecology Progress Series 220, 25-32.

de Wilde, P., Duineveld, G.C.A., Berghuis, E.M., Lavaleye, M., Kok, A., 1998. Latesummer mass deposition of gelatinous phytodetritus along the slope of the N.W. European Continental Margin. Progress in Oceanography 42, 165-187.

Duineveld, G.C.A., Lavaleye, M., Berghuis, E.M., de Wilde, P., Van der Weele, J., Kok, A., Batten, S.D., de Leeuw, J., 1997. Patterns of benthic fauna and benthic respiration on the Celtic continental margin in relation to the distribution of phytodetritus. Internationale Revue der Gesamten Hydrobiologie 82, 395-424.

Gage, J.D., Bett, B.J., 2005. Deep-sea benthic sampling. In: Holmes, N.A. and McIntyre, A.D. (Eds). Methods for the Study of the Marine Benthos. Blackwell Scientific Publications, Oxford, pp. 273-325.

George, S.B., Lawrence, A.L., 2002. The effect of carotenoids on egg production and larval development of the edible sea urchin, Lytechinus variegatus: The role of adult and larval diets. World Aquaculture 33, 55-61. 
George, S.B., Lawrence, J.M., Lawrence, A.L., Smiley, J., Plank, L., 2001.

Carotenoids in the adult diet enhance egg and juvenile production in the sea urchin Lytechinus variegatus. Aquaculture 199, 353-369.

George, S.B., Young, C.M., 1998. Can bathyal echinoids maintain the production of high quality eggs regardless of diet? Echinoderms: Proceedings of the 9th International Echinoderm Conference, San Francisco, USA. City, pp. 666.

Gibb, S., Barlow, R.G., Cummings, D.G., Rees, N., W, Trees, C.C., Holligan, P., Suggett, D., 2000. Surface phytoplankton pigment distributions in the Atlantic Ocean: an assessment of basin scale variability between $50^{\circ} \mathrm{N}$ and $50^{\circ} \mathrm{S}$. Progress in Oceanography 45, 339-368.

Ginger, M.L., Billett, D.S.M., Mackenzie, K.L., Kiriakoulakis, K., Neto, R.R., Boardman, D., Santos, V., Horsfall, I., Wolff, G., 2001. Organic matter assimilation and selective feeding by holothurians in the deep sea: some observations and comments. Progress in Oceanography 50, 407-421.

Ginger, M.L., Santos, V.L.C.S., Wolff, G.A., 2000. A preliminary investigation of the lipids of abyssal holothurians from the north-east Atlantic Ocean. Journal of the Marine Biological Association, UK 80, 139-146.

Howell, K., Billett, D.S.M., Tyler, P.A., Davidson, R., 2004. Feeding ecology of deep-sea seastars (Echinodermata: Asteroidea): a pigment biomarker approach. Marine Ecology Progress Series 286, 103-110.

Hudson, I.R., 2004. Deep-sea biology food for thought? Examining dietary selection and resource allocation in deep-sea holothurians. Ph.D. Thesis. University of Southampton. Southampton, UK, unpublished

Hudson, I.R., Pond, D.W., Billett, D.S.M., Tyler, P.A., Lampitt, R.S., Wolff, G.A., 2004. Temporal variations in fatty acid composition of deep-sea holothurians: evidence of bentho-pelagic coupling. Marine Ecology Progress Series 281, 109-120.

Hudson, I.R., Wigham, B.D., Billett, D.S.M., Tyler, P.A., 2003. Seasonality and selectivity in the feeding ecology and reproductive biology of deep-sea bathyal holothurians. Progress in Oceanography 59, 381-407.

Iken, K., Brey, T., Wand, U., Voight, I., Junghans, P., 2001. Food web structure of the benthic community at Porcupine Abyssal Plain (N. Atlantic): a stable isotope analysis. Progress in Oceanography 50, 383-405.

Jeffrey, S.W., Mantoura, R.F.C., Wright, S.W., 1997. Phytoplankton Pigments in Oceanography. United Nations Educational, Scientific and Cultural Organization, Paris.

Khripounoff, A., Sibuet, M., 1980. La nutrition d'echinodermes abyssaux I. Alimentation des holothuries. Marine Biology 60, 17-26. 
Kiriakoulakis, K., Bett, B.J., White, M., Wolff, G.A., 2004. Organic biogeochemistry of the Darwin Mounds, a deep-water coral ecosystem, of the NE Atlantic. Deep-Sea Research Part I 51 (12), 1937-1954.

Kiriakoulakis, K., Stutt, E., Rowland, S.J., Vangriesheim, A., Lampitt, R.S., Wolff, G., 2001. Controls on the organic chemical composition of settling particles in the Northeast Atlantic Ocean. Progress in Oceanography 50, 65-87.

Krinsky, N.I., 1994. The biological properties of carotenoids. Pure and Applied Chemistry 86 (5), 1003-1010.

Lampitt, R.S., Bett, B.J., Kiriakoulakis, K., Popova, E.E., Ragueneau, O., Vangriesheim, A., Wolff, G.A., 2001. Material supply to the abyssal seafloor in the Northeast Atlantic. Progress in Oceanography 50, 27-63.

Lampitt, R.S., Salter, I., de Cuevas, B.A., Hartman, S., Larkin, K.E., Pebody, C.A., Long-term variability of downward particle flux in the deep Northeast Atlantic: causes and trends. Deep-Sea Research Part II this volume.

Lee, C., Wakeham, S.G., Hedges, J.I., 2000. Composition and flux of particulate amino acids and chloropigments in equatorial Pacific seawater and sediments. DeepSea Research Part I 47, 1535-1568.

Lotocka, M., Styczynska-Jurewicz, E., Bledzki, L.A., 2004. Changes in carotenoid composition in different developmental stages of copepods: Pseudocalanus acuspes Giesbrecht and Acartia spp. Journal of plankton research 26 (2), 159-166.

Matsuno, T., 2001. Aquatic animal carotenoids. Fisheries science 67, 771-783.

Moore, H.M., Roberts, D., 1994. Feeding strategies in abyssal holothurians. In: David, B., Guille, A., Feral, J.-P. and Roux, M. (Eds). Echinoderms Through Time. Balkema, Rotterdam, pp. 531-537.

Neto, R.R., Wolff, G.A., Billett, D.S.M., Mackenzie, K.L., Thomson, A., 2006. The influence of changing food supply on the lipid biochemistry of deep-sea holothurians. Deep-Sea Research Part I 53, 516-527.

Olson, V.A., Owens, I.P.F., 1998. Costly sexual signals: are carotenoids rare, risky or required? Trends in Ecology and Evolution 13 (12), 510-514.

Ramirez-Llodra, E., Reid, W.D.K., Billett, D.S.M., 2005. Long-term changes in reproductive patterns of the holothurian Oneirophanta mutabilis from the Porcupine Abyssal Plain. Marine Biology 146, 683-693.

Repeta, D.J., Gagosian, R.B., 1987. Carotenoid diagenesis in recent marine sediments - I. The Peru continental shelf $\left(15^{\circ} \mathrm{S}, 75^{\circ} \mathrm{W}\right)$. Geochimica et Cosmochimica Acta 51, 1001-1009.

Riaux-Gobin, C., Hargraves, P.E., Neveux, J., Oriol, L., Vetion, G., 1997. Microphyte pigments and resting spores at the water-sediment interface in the Subantarctic deep 
sea (Indian sector of the Southern Ocean). Deep-Sea Research Part II 44 (5), 10331051.

Rice, A.L., Thurston, M.H., New, A.L., 1990. Dense aggregations of a hexactinellid sponge, Pheronema carpenteri, in the Porcupine Seabight (Northeast Atlantic Ocean), and possible causes. Progress in Oceanography 24, 179-196.

Richardson, A.J., Schoeman, D.S., 2004. Climate impact on plankton ecosystems in the Northeast Atlantic. Science 305, 1609-1612.

Roberts, D., Gebruk, A., Levin, V., Manship, B.A.D., 2000. Feeding and digestive strategies in deposit-feeding holothurians. Oceanography and Marine Biology: an Annual Review 38, 257-310.

Ruhl, H.A., Smith, K.L., 2004. Shifts in deep-sea community structure linked to climate and food supply. Science 305, 513-515.

Salter, I., 2007. Particle fluxes in the North-East Atlantic and the Southern Ocean. Ph.D. Thesis. University of Southampton. Southampton, UK, unpublished

Santos, V., Billett, D.S.M., Rice, A.L., Wolff, G.A., 1994. Organic matter in the deepsea sediments from the Porcupine Abyssal Plain in the northeast Atlantic Ocean. ILipids. Deep-Sea Research Part I 41 (5/6), 787-819.

Smith, K.L., Kaufmann, R.S., Baldwin, R.J., Carlucci, A.F., 2001. Pelagic-benthic coupling in the abyssal eastern North Pacific: An 8 year time-series study of food supply and demand. Limnology and Oceanography 46 (3), 543-556.

Smith, T., 2008. Sexual Biochemistry in the Deep Sea: The link between phytoplankton and abyssal holothurians. Ph.D. Thesis. University of Southampton. Southampton, UK, unpublished

Smythe-Wright, D., Boswell, S., Kim, Y.-N., Kemp, A.E., Spatio-temporal changes in the distribution of phytopigments and phytoplanktonic groups at the PAP site. DeepSea Research Part II this volume.

Thiel, H., Pfannkuche, O., Schriever, G., Lochte, K., Gooday, A.J., Hemleben, C., Mantoura, R.F.C., Turley, C.M., Patching, J.W., Riemann, F., 1989. Phytodetritus on the deep-sea floor in a central oceanic region of the Northeast Atlantic. Biological Oceanography 6 (2), 203-239.

Tsushima, M., Kawakami, T., Mine, M., Matsuno, T., 1997. The role of carotenoids in the development of the sea urchin Pseudocentrotus depressus. Invertebrate Reproduction and Development 32, 149-153.

Turner, J.T., 2002. Zooplankton feacal pellets, marine snow and sinking phytoplankton blooms. Aquatic Microbial Ecology 27, 57-102. 
Turnewitsch, R., Witte, U., Gerhard, G., 2000. Bioturbation in the abyssal Arabian Sea: influence of fauna and food supply. Deep-Sea Research Part II 47 (14), 2877 2911.

Tyler, P.A., Billett, D.S.M., Gage, J.D., 1987. The ecology and reproductive biology of Cherbonniera utriculus and Molpadia blakei from the N.E. Atlantic. Journal of the Marine Biological Association, UK 67, 385-397.

Wigham, B.D., 2002. The 'Amperima Event' analysis of community change in the abyssal Northeast Atlantic Ocean. Ph.D. Thesis. University of Southampton. Southampton, UK, unpublished

Wigham, B.D., Hudson, I.R., Billett, D.S.M., Wolff, G.A., 2003a. Is long term change in the abyssal Northeast Atlantic driven by qualitative changes in export flux?

Evidence from selective feeding in deep-sea holothurians. Progress in Oceanography 59, 409-441.

Wigham, B.D., Tyler, P.A., Billett, D.S.M., 2003b. Reproductive biology of the abyssal holothurian Amperima rosea: an opportunistic response to variable flux of surface derived organic matter. Journal of the Marine Biological Association, UK 83, 175-188.

Witbaard, R., Duineveld, A., Kok, A., van der Weele, J., Berghuis, E.M., 2000. The benthic response to the seasonal deposition of phytopigments at the Porcupine Abyssal Plain in the northeast Atlantic. Journal of Sea Research 43, 15-31.

Witbaard, R., Duineveld, A., Kok, A., van der Weele, J., Berghuis, E.M., 2001. The response of Oneirophanta mutabilis (Holothuroidea) to the seasonal deposition of phytopigments at the Porcupine Abyssal Plain in the Northeast Atlantic. Progress in Oceanography 50, 423-441.

Zubkov, M.V., Sleigh, M.A., Burkill, P., Leakey , R.J.G., 2000. Picoplankton community structure on the Atlantic Meridional Transect: a comparison between seasons. Progress in Oceanography 45, 369-386. 


\begin{tabular}{|c|c|c|c|c|c|}
\hline Station & Date & Lat (N) & Long (W) & Depth & Samples Collected \\
\hline $56515 \# 1$ & $21 / 06 / 04$ & $48^{\circ} 58.30^{\prime}$ & $16^{\circ} 18.50^{\prime}$ & $4845 \mathrm{~m}$ & $\begin{array}{l}\text { Amperima rosea }(\mathrm{n}=5) \text {, Oneirophanta mutabilis } \\
(\mathrm{n}=5) \text {, Peniagone diaphana }(\mathrm{n}=4)\end{array}$ \\
\hline $56523 \# 1$ & $24 / 06 / 04$ & $48^{\circ} 52.90^{\prime}$ & $16^{\circ} 30.20^{\prime}$ & $4844 \mathrm{~m}$ & $\begin{array}{l}\text { Amperima rosea }(\mathrm{n}=10) \text {, Oneirophanta mutabilis } \\
(\mathrm{n}=4), \text { Psychropotes longicauda }(\mathrm{n}=5), \\
\text { Paroriza prouhoi }(\mathrm{n}=5)\end{array}$ \\
\hline $15711 \# 1$ & $17 / 07 / 05$ & $48^{\circ} 54.00^{\prime}$ & $16^{\circ} 20.00^{\prime}$ & $4840 \mathrm{~m}$ & $\begin{array}{l}\text { Oneirophanta mutabilis }(\mathrm{n}=4), \text { Paroriza prouhoi } \\
(\mathrm{n}=4), \text { Psychropotes longicauda }(\mathrm{n}=2), \\
\text { Pseudostichopus aemulatus, Pseudostichopus } \\
\text { villosus }(\mathrm{n}=3), \text { Molpadia blakei }(\mathrm{n}=1)\end{array}$ \\
\hline $15717 \# 1$ & $19 / 07 / 05$ & $48^{\circ} 46.60^{\prime}$ & $16^{\circ} 29.80^{\prime}$ & $4842 \mathrm{~m}$ & $\begin{array}{l}\text { Oneirophanta mutabilis }(\mathrm{n}=1), \text { Molpadia blakei } \\
(\mathrm{n}=4), \text { Psychropotes longicauda }(\mathrm{n}=2) \\
\text { Pseudostichopus villosus }(\mathrm{n}=4)\end{array}$ \\
\hline $56502 \# 1$ & $19 / 06 / 04$ & $48^{\circ} 51.20^{\prime}$ & $16^{\circ} 29.20^{\prime}$ & $4835 \mathrm{~m}$ & Sediment core and phytodetritus $(\mathrm{n}=1)$ \\
\hline $56508 \# 1$ & $20 / 06 / 04$ & $48^{\circ} 51.00^{\prime}$ & $16^{\circ} 30.00^{\prime}$ & $4838 \mathrm{~m}$ & Sediment core $(n=1)$ and phytodetritus $(n=2)$ \\
\hline $56519 \# 1$ & $22 / 06 / 04$ & $48^{\circ} 51.00^{\prime}$ & $16^{\circ} 29.90^{\prime}$ & $4833 \mathrm{~m}$ & Sediment core and phytodetritus $(n=1)$ \\
\hline $15720 \# 1$ & $19 / 07 / 05$ & $48^{\circ} 52.10^{\prime}$ & $16^{\circ} 29.80^{\prime}$ & $4838 \mathrm{~m}$ & Sediment cores and phytodetritus $(n=1)$ \\
\hline $15724 \# 1$ & $20 / 07 / 05$ & $48^{\circ} 52.00^{\prime}$ & $16^{\circ} 29.70^{\prime}$ & $4836 \mathrm{~m}$ & Sediment cores and phytodetritus $(n=2)$ \\
\hline
\end{tabular}

Table 1. Holothurian and sediment samples collected during RRS Charles Darwin cruise CD158, June 2004 and RRS Discovery cruise D296, July 2005 to the Porcupine Abyssal Plain, Northeast Atlantic. (Position at start of trawl (ship's position) is given for trawling activity).

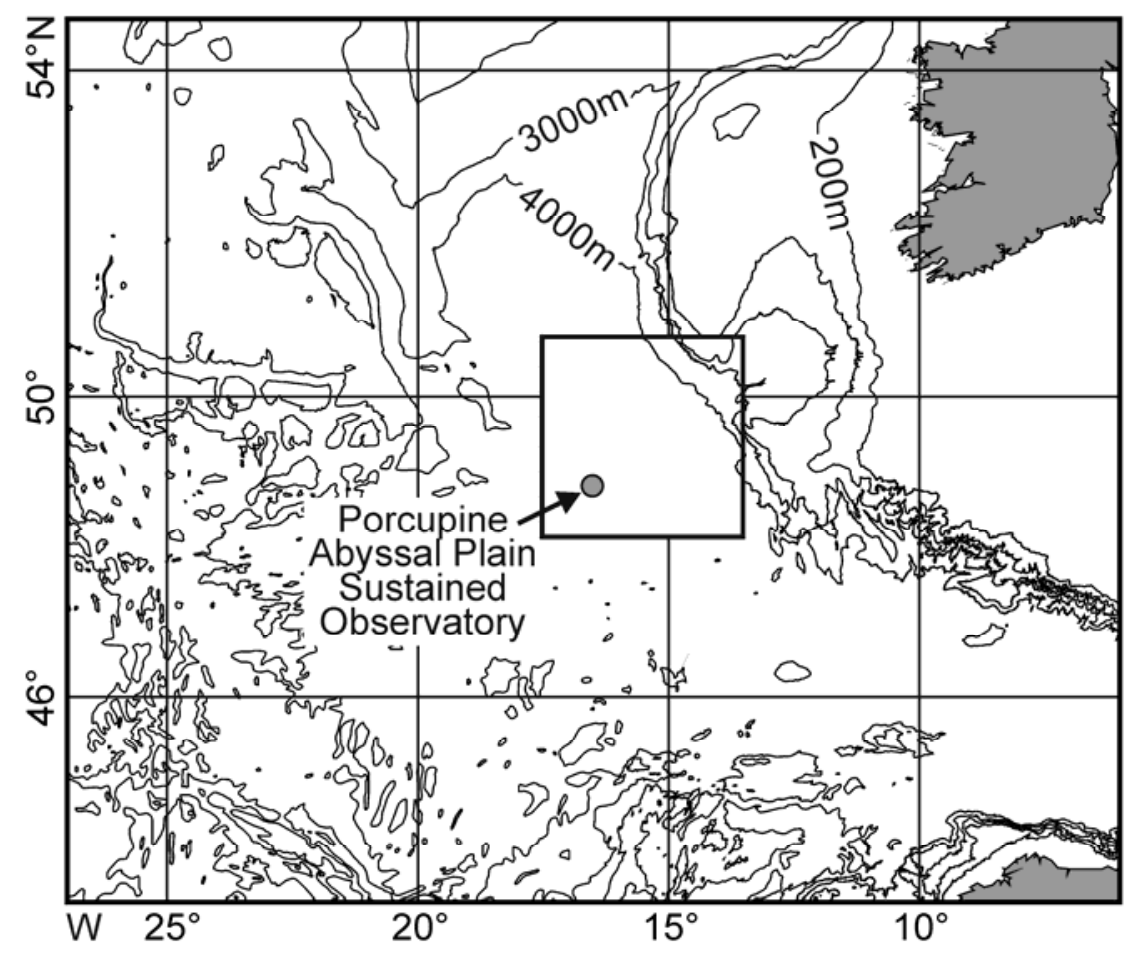

Figure 1. Map of the Porcupine Abyssal Plain time-series observatory. 
a)

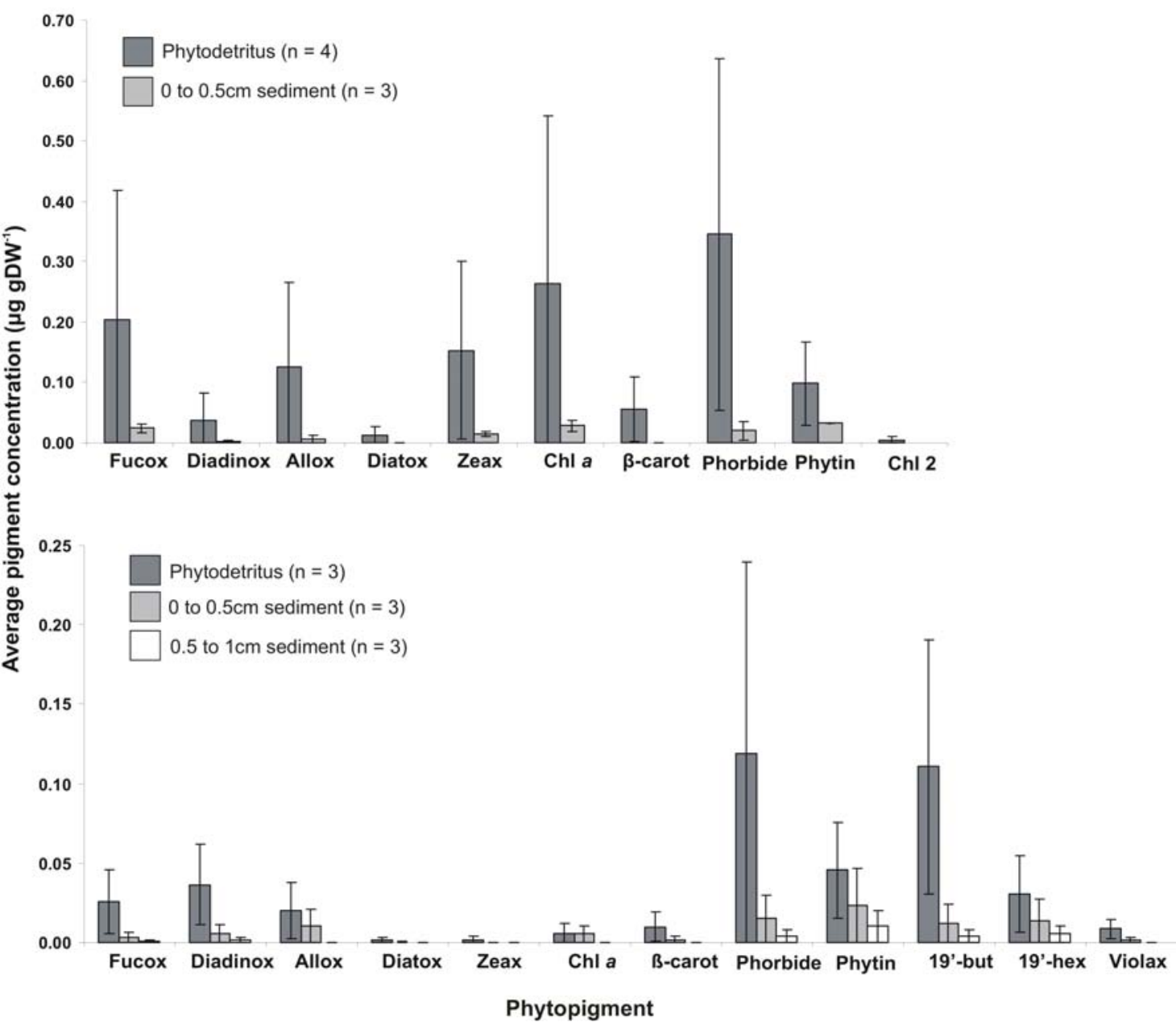

Figure 2. Phytopigments found in the phytodetritus, 0 to $0.5 \mathrm{~cm}$ and 0.5 to $1 \mathrm{~cm}$ of sediment from (a) June 2004 and (b) July 2005 (mean $\mu$ g gDW-1 \pm SD). Fucox = fucoxanthin; Diad = diadinoxanthin; Allox = alloxanthin; Diatox $=$ diatoxanthin; Zeax $=$ zeaxanthin $;$ Chl a $=$ chlorophyll $\mathrm{a} ; \beta$-carot $=\beta$-carotene; Phorbide $=$ phaeophorbide; Phytin = phaeophytin; 19'but = 19'-butanoyloxyfucoxanthin; 19'-hex = 19'hexanoyloxyfucoxanthin; Violax = violaxanthin; Chl 2 = chlorophyll c2. (note different scales on y-axis). 


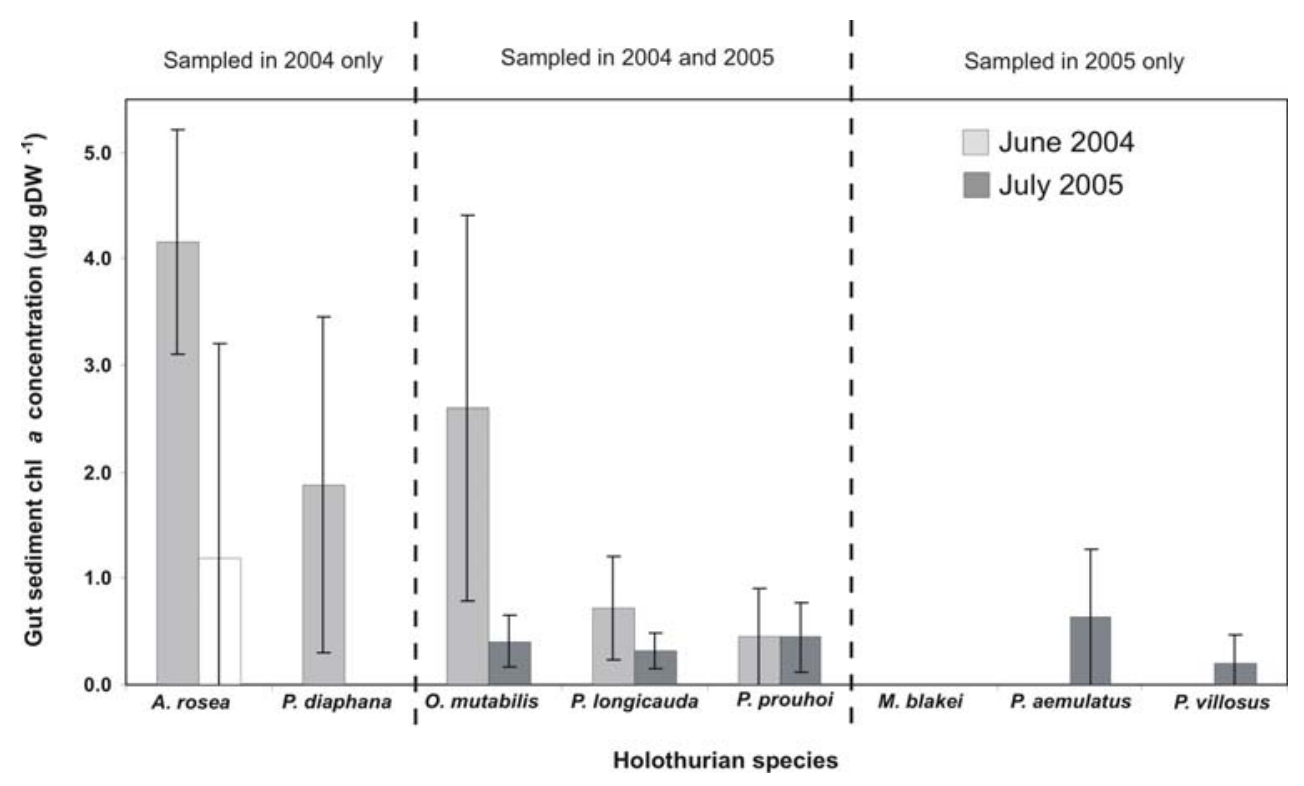

Figure 3. Chlorophyll $a$ concentration (mean $\mu \mathrm{g}$ gDW-1 $\pm \mathrm{SD}$ ) in the gut contents of holothurian species sampled at the PAP in June 2004 (light grey) and July 2005 (dark grey). (Amperima rosea mean gut chlorophyll a concentration based on all samples, including samples with empty guts, indicated by white histogram - see text). 


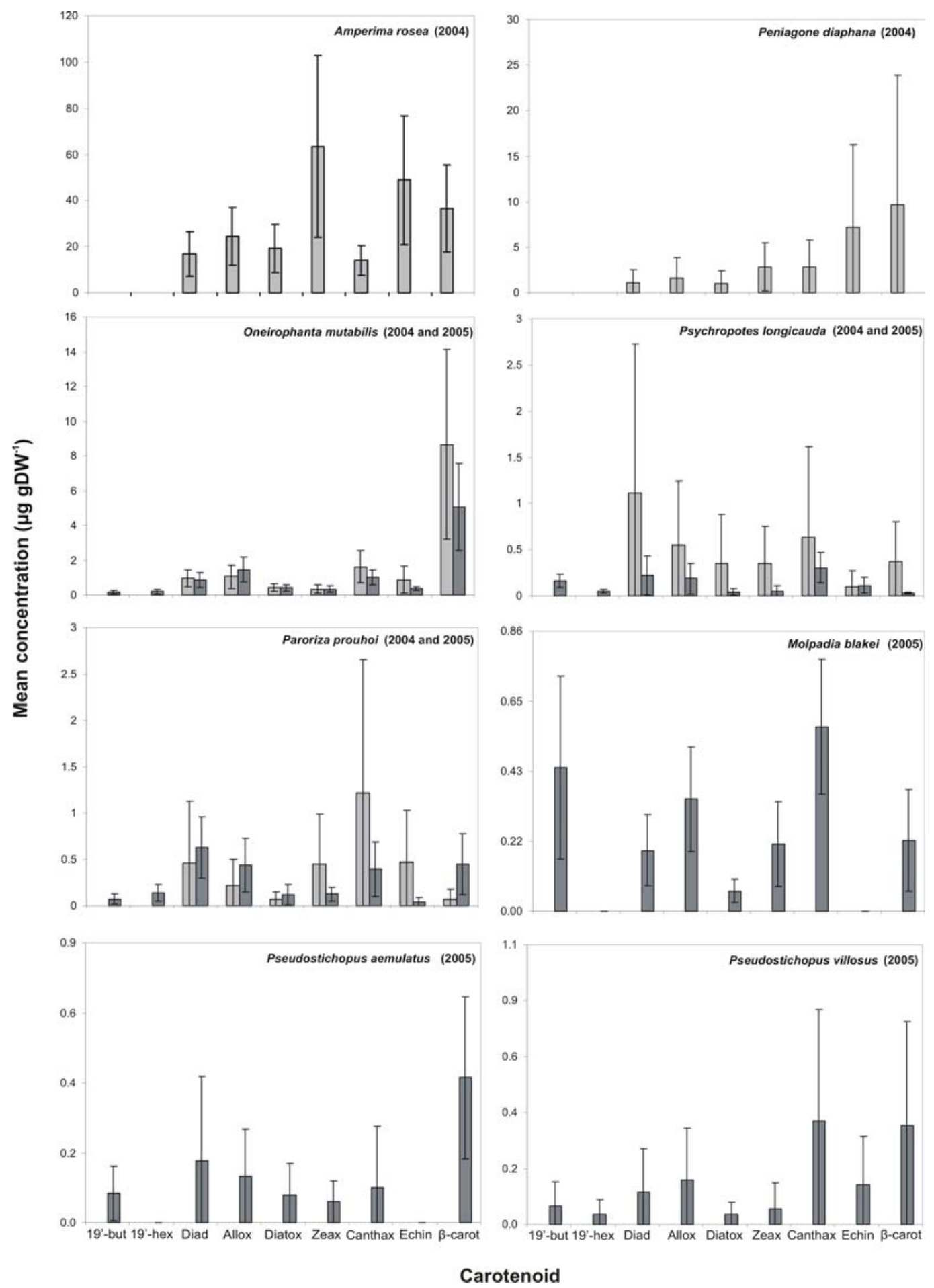

Figure 4. Carotenoid concentrations (mean $\mu \mathrm{g} g D W-1 \pm \mathrm{SD}$ ) in the ovaries of holothurians sampled at the PAP in June 2004 (light grey) and July 2005 (dark grey). Diad $=$ diadinoxanthin; Allox = alloxanthin; Diatox $=$ diatoxanthin; $Z$ Zeax = zeaxanthin; 
Canthax $=$ canthaxanthin; Echin $=$ echinenone; $\beta$-carot $=\beta$-carotene (note different scales on y-axis).

a)

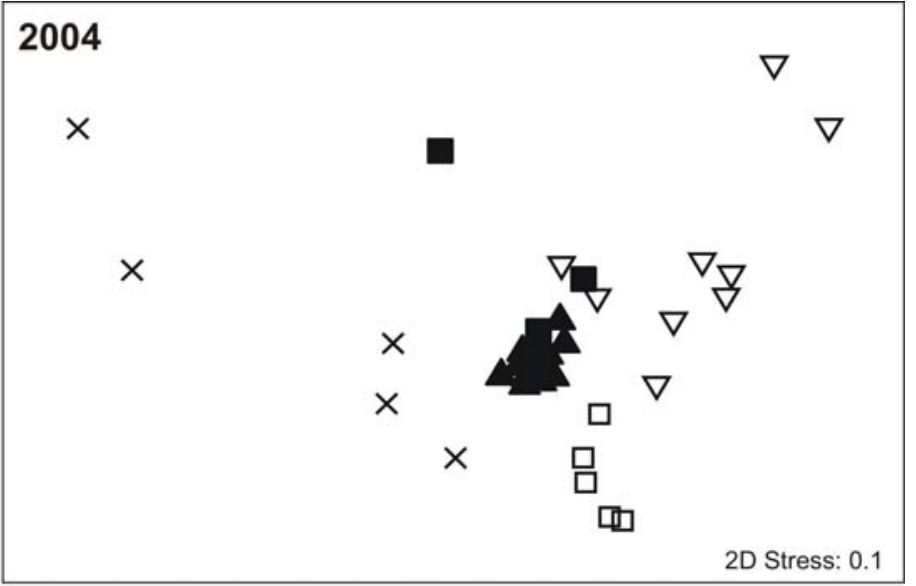

b)

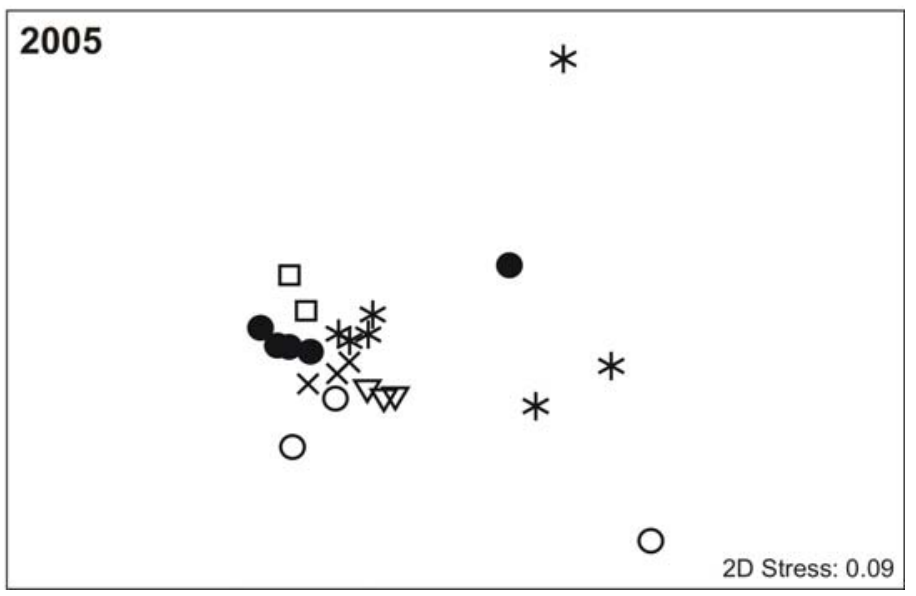

Figure 5. MDS ordination of 37 individual holothurian ovary samples from PAP June 2004 (a) and July 2005 (b), based on $\sqrt{ }$-transformed pigment percentage contributions and Bray-Curtis similarities. Key: $\boldsymbol{\Delta}=$ Amperima rosea; $\boldsymbol{\nabla}=$ Oneirophanta mutabilis; - = Peniagone diaphana; $\square=$ Psychropotes longicauda; $\mathbf{x}=$ Paroriza prouhoi; $\bullet$ = Molpadia blakei; o = Pseudostichopus aemulatus; $*$ = Pseudostichopus villosus. 


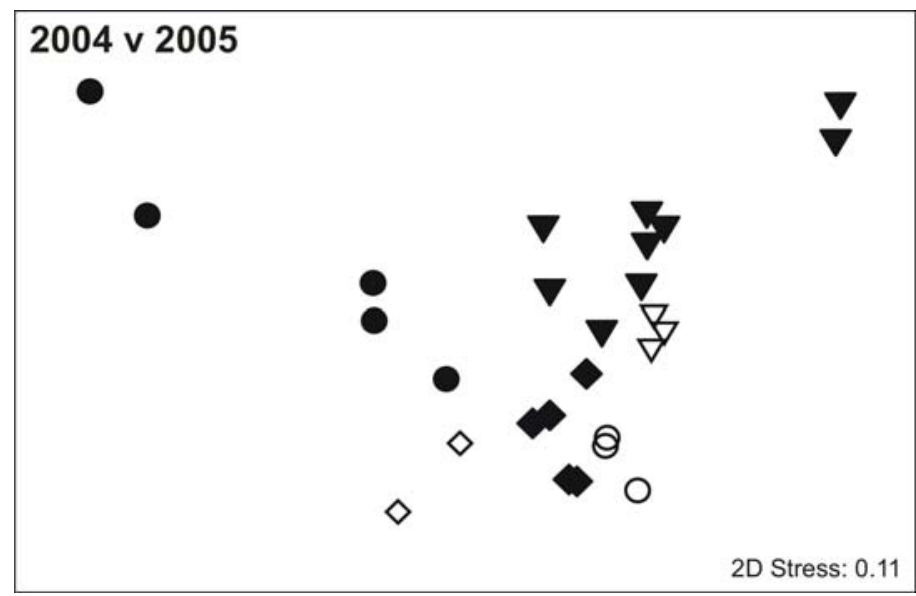

Figure 6. MDS ordination of 23 individual holothurian ovary samples from PAP June 2004 and July 2005, based on $\sqrt{ }$-transformed pigment percentage contributions and Bray-Curtis similarities. Key: $\boldsymbol{\nabla}=$ Oneirophanta mutabilis June 2004; $\boldsymbol{\nabla}=$ Oneirophanta mutabilis July 2005; $\diamond=$ Psychropotes longicauda June 2004; $\diamond=$ Psychropotes longicauda July 2005; • = Paroriza prouhoi June 2004; ○ = Paroriza prouhoi July 2005. 